\title{
Comparison of Fish Pond Waste Water with Manures under Garden Egg in Nigeria
}

\author{
Dominic J. Udoh ${ }^{1}$, Otobong B. Iren ${ }^{2} \&$ Jeremiah E. Jonathan ${ }^{3}$ \\ ${ }^{1}$ Department of Soil Science, Akwa Ibom State University, Obiokpa, Akwa Ibom State, Nigeria \\ ${ }^{2}$ Department of Soil Science, University of Calabar, Calabar, Cross River State, Nigeria \\ ${ }^{3}$ Department of Soil Science and Land Resources Management, University of Uyo, Uyo, Nigeria \\ Correspondence: Otobong B. Iren, Department of Soil Science, University of Calabar, Calabar, Cross River State, \\ Nigeria. Tel: 234-803-506-8991. E-mail:myirenlady@gmail.com
}

Received: June 2, 2016 Accepted: June 26, 2016 Online Published: July 19, 2016

doi: 10.5539/enrr.v6n3p58 URL: http://dx.doi.org/10.5539/enrr.v6n3p58

\begin{abstract}
Two field experiments were conducted from 2012 to 2013 cropping seasons to evaluate the efficacy and also determine the optimum rates of application for fish pond waste water in comparison with three other manures including one inorganic fertilizer and two organic manures under garden egg (Solanum spp.) crop.Garden egg was fertilized with pond waste water (PW), poultry manure (PM), pig manure (PG) and NPK15:15:15 at equivalent nitrogen $(\mathrm{N})$ rates $(0,150,300,450 \mathrm{~kg} / \mathrm{ha})$. The treatments were arranged in a split plot under randomized complete block design (RCBD). The results obtained indicated a slight drop in soil $\mathrm{pH}$ but soil OM, total $\mathrm{N}$, available $\mathrm{P}$, exchangeable $\mathrm{Ca}$ and $\mathrm{K}$ increased generally with increasing rates of manures. The PW and PG treatments supported significantly $(\mathrm{P}<0.05)$ the highest yields of the crop compared to PM and NPK with the 150 and $300 \mathrm{~kg} /$ ha treatments recording the highest increase. These results have shown that under the high rainfall and acidic soil conditions of Akwa Ibom State in Nigeria, PW is useful for the improvement of soil conditions and achievement of higher crop yields when applied at rates that supply $\mathrm{N}$ in the range of $150-300 \mathrm{~kg} / \mathrm{ha}$.
\end{abstract}

Keywords: fish pond waste water, garden egg, NPK, pig manure, poultry manure, soil properties

\section{Introduction}

Acid sandy ultisols, which are common in the humid, rain-forest zone of south eastern Nigeria, are inherently infertile, especially under the intensive cultivation that has been occasioned by reduction in fallow periods caused by population pressure and industrialization. The usual approach of maintaining fertility has simply been the application of recommended doses of inorganic fertilizers. The quick and massive increase observed in the productivity of modern agriculture has largely been attributed to the use of fertilizers, such that most production programmes became almost entirely dependent on fertilizer use. Such dependence has been bolstered by the fact that inorganic fertilizers are easier and cheaper to handle, on account of their very high nutrient content - which remain relatively stable over time - when compared with manure fertilizers.

Manures are bio-active under moist conditions and change with time, being thus not easy to standardise in regard to nutrient analyses. Nevertheless, more and more people are turning to organic foods, supposedly produced with organic fertilizers that carry no contaminating chemicals. The use of certain organic manures that are relatively high in nutrient analyses - such as those of poultry, pigs, cattle, goat is drawing more attention (Iren, Asawalam, Osodeke \& John, 2012). Iren, Akpan, Ediene and Asanga (2015) have reported on the positive impacts of organic manures on the sustained production of waterleaf. When applied on acid sandy ultisols under a high rainfall regime, the nutrients supplied in inorganic fertilizers are easily lost through leaching, surface runoff or soil erosion. Indeed high dependence on inorganic fertilizers in the humid zones of the tropics is becoming less preferable and uneconomical, including the need for frequent re-applications in order to sustain fertility. Organic fertilizers improve soil CEC, nutrient stock, soil structure, base saturation and bulk density.

Applications of large doses of manures could, however, cause environmental hazards - stream and river pollution, soil acidification and soil salinity, but this applies both ways! Hati, Swarup, Dwivedi, Misra and Bandyopadhyay (2007) and Yu et al. (2012) reported on the positive impacts of organic fertilizers on the root growth and yield of maize. Ayeni and Adetunji (2010) reported on the highly positive impact of integrated applications of poultry 
manure and mineral fertilizer on nutrient uptake and yield of maize. John, Uwah, Iren,and Akpan (2013) showed that soils amended with animal manures significantly improved soil productivity and the yield of maize. Other challenges of using organic manures include bulkiness, low nutrient analyses, and difficulty of quality standardization and cumbersomeness in application. These can be minimized, however, through a processing of the manures (Blair, Faulkner, Till, \& Prince, 2003); selection of manures that are available at close proximity, and use of manures with higher nutrient analyses that can also be conveniently mixed with inorganic fertilizers.

The development of integrated farming has afforded better opportunity for the testing of different manures, singly or in combination. It is equally necessary to verify the proper rates of the manure fertilizers to apply under different soil and climatic conditions. Fish pond waste water, for instance, has been considered a useful fertilizer material. According to FAO report (2014), the combination of fish farming and crop cultivation is well developed in China where the nutrient-rich residue that settles in fish ponds as silt, while indicating deteriorated water on the one hand, rather represents high-quality manure for crop cultivation, on the other. The crops are in turn used in the preparation of fish feeds, and so the pond silt constitutes the link in fish and crop integration. The objectives of this study were to assess the comparative fertilizer quality of fish pond waste water (PW) with poultry manure (PM), pig manure (PG) and NPK fertilizer on soil properties and growth of garden egg crop on an ultisol, and also to determine the optimum rate of application of PW.

\section{Materials and Methods}

\subsection{Site Conditions}

The experiment was conducted at Domita Farms located on Ring Road 4, off Nwaniba Road, Uyo, Akwa Ibom State. The farm operates an integrated programme of crop, livestock and aquaculture production, as well as agro-processing. The 'apparent' waste products of one project are applied as inputs to others. The soils of the area are coastal plain, acid sand ultisols (Acrisols and Ferralsols in the new WRB soil classification system), which require good management to be productive. Uyo lies between latitudes $7^{\circ} 47^{\prime}$ and $8^{\circ} 3^{\prime} \mathrm{N}$, and longitudes $4^{\circ} 52^{\prime}$ and $5^{\circ} 7^{\prime} \mathrm{E}$. The farm is located on a nearly flat upland plain formerly covered by secondary forests of wild palm trees and hard woods. The climate is sub-equatorial with an annual rainfall that ranges from $2500 \mathrm{~mm}-3500 \mathrm{~mm}$; relative humidity of 75 $95 \%$ and mean Minimum/Maximum temperature of $24^{\circ} \mathrm{C} / 30^{\circ} \mathrm{C}$ (Uniuyo Agromet, 2015).

\subsection{Materials Used}

Two field experiments were conducted to compare the manures: these involve testing the manures under garden egg crop in 2012 and 2013 dry season cropping. The manures, PM, PG and PW used in the experiments were obtained from Domita Farms. NPK $15^{3}$ was bought from the market.Garden egg seeds were also obtained from Domita Farms. Samples of the manures were sent to the laboratory for analyses. Fish pond waste water was dried and calibrated to establish the volumes that would supply equivalent amounts of $\mathrm{N}$ nutrient to be applied ( $\mathrm{N}$ as the reference factor) in comparison with the other manures.

\subsection{Field Experiments}

The field site was selected, cleared and herbicides were used in destroying stubborn weeds. Plots were tilled to suit the cultivation of garden egg. The plots were laid out as a split plot in RCBD, with four (4) main treatments (manures) and four (4) sub-treatments (fertilizer rates), all in 3 replicates (total of 48 plots, each measuring $2 \mathrm{~m} \times 2$ $\mathrm{m}$, with a space of $0.5 \mathrm{~m}$ separating the plots and $1.2 \mathrm{~m}$ separating the blocks). The PM and PG manures were composted before use. The 3 solid materials (PM, PG and NPK) were applied by spreading appropriate rates on the plots and incorporating them into the soil, while $\mathrm{PW}$ was applied by pouring aliquot quantities per treatment rate on each plot. The manures and NPK $15^{3}$ in this experiment were measured to supply nitrogen at $0,150,300$, and $450 \mathrm{kgha}^{-1}$ (Table 1). After application, the plots were lightly mulched and the manures allowed equilibration for one week before garden egg seedlings were planted. The growth and development of the crop was closely observed, and measurements of plant height, leaf surface area, and later, fruit yield taken. Composite samples of the soil were taken before and after experiment for routine analysis.

\subsection{Laboratory Methods}

The composite soil samples obtained before and after experiment were air dried and passed through a $2 \mathrm{~mm}$ sieve and analysed using standard procedures as outlined by Udo, Ogunwale, Ibia, Ano \& Esu (2009) for particle size using Bouyoucos hydrometer method; $\mathrm{pH}$ (glass electrode meter in 1:2.5 soil/water); organic matter by Walkley and Black wet oxidation method; electrical conductivity was measured in a soil/water slurry with a conductivity bridge; $\mathrm{Ca}, \mathrm{Mg}, \mathrm{K}$ and $\mathrm{Na}$ were extracted with $1 \mathrm{M} \mathrm{NH}_{4} \mathrm{OAc}$; then $\mathrm{Ca}$ and $\mathrm{Mg}$ determined by EDTA titration and $\mathrm{K}, \mathrm{Na}$ by flame photometer. Total $\mathrm{N}$ was determined by the micro-Kjeldhal digestion method. Available phosphorus (P) was extracted by the Bray 1 extraction method, and the content of $\mathrm{P}$ was determined 
colorimetrically using a Technico AAII auto analyser (Technico, Oakland, Calif). Effective cation exchange capacity (ECEC) was determined by the summation method, where ECEC = TEB + TEA (TEB - total exchangeable bases; TEA - total exchangeable acidity, determined with $\mathrm{KCl}$, using displacement method).

Percent base saturation was calculated as:

$$
\% B S=\frac{\text { TEB }}{\text { CEC }} X 100
$$

Data collected were analyzed according to the procedures outlined by Gomez and Gomez (1984) for randomized complete block design using Genstat package and significant means were compared using Fisher's least significant difference (FLSD) at $5 \%$ level of probability.

Table 1. Quantities of manures and NPK applied*

\begin{tabular}{ccccc}
\hline \multirow{2}{*}{$\begin{array}{c}\text { Equivalent } \\
\text { N-Rate (kg/ha) }\end{array}$} & \multicolumn{4}{c}{ Fertilizer Type and N content } \\
\cline { 2 - 5 } & PM (N=1.5\%) & PG $(\mathrm{N}=0.75 \%)$ & PW $(\mathrm{N}=1.3 \%)$ & NPK (N =15 \%) \\
\hline 0 (Control) & 0 & 0 & 0 & 0 \\
150 & 10 & 20 & 12 & 1 \\
300 & 20 & 40 & 24 & 2 \\
450 & 30 & 60 & 34 & 3 \\
\hline
\end{tabular}

*Each manure was tested for $\mathrm{N}$ content, as shown, and the quantity to apply calculated to provide $\mathrm{N}$ at the rates indicated.

\section{Results and Discussion}

\subsection{Chemical Composition of Organic Fertilizers}

The chemical characteristics of the four fertilizer materials used are shown in Table 2. The three manures indicated similar levels of alkaline reaction when tested in water slurry. Although microbial decomposition generates some acidity when organic matter is decomposed, the alkaline levels of these manures indicate them as not being direct soil acidifiers. Pond water manure is low in $\mathrm{K}$ and P but high in Ca and Mg. Kendrick (2005) observed such a trend with pond waste water in Egypt. This may result partly from the fact that fish feeds are usually enriched with $\mathrm{Ca}$ and associated $\mathrm{Mg}$ to aid bone development.

Table 2. Chemical Properties of the Manures/Fertilizer Used

\begin{tabular}{|c|c|c|c|c|c|c|c|c|}
\hline \multirow{2}{*}{ Manure } & \multirow{2}{*}{$\begin{array}{c}\mathrm{pH} \\
\left(\mathrm{H}_{2} \mathrm{O}\right)\end{array}$} & \multirow{2}{*}{$\begin{array}{c}\mathrm{EC} \\
\mathrm{dSm}^{-1}\end{array}$} & \multirow{2}{*}{$\begin{array}{c}\text { OM } \\
\%\end{array}$} & \multirow{2}{*}{$\begin{array}{c}\text { Total } \mathrm{N} \\
\%\end{array}$} & $\mathrm{P}$ & $\mathrm{K}$ & $\mathrm{Ca}$ & $\mathrm{Mg}$ \\
\hline & & & & & \multicolumn{4}{|c|}{-------- mg/kg --------- } \\
\hline PM & 8.7 & 1.36 & 53 & 1.50 & 1080 & 3600 & 1884 & 6010 \\
\hline PG & 8.1 & 1.97 & 27 & 0.75 & 1020 & 3200 & 2011 & 4860 \\
\hline PW & 8.7 & 2.50 & 47 & 1.32 & 90 & 4000 & 1991 & 44 \\
\hline NPK: $15^{3}$ & - & - & - & $15 \%$ & $15 \%$ & $15 \%-$ & - & - \\
\hline
\end{tabular}

$\mathrm{PM}=$ Poultry manure; $\mathrm{PG}=$ Pig manure; $\mathrm{PW}=$ Pond waste water.

\subsection{Effects of Manures and Rates of Application on Soil Properties}

The effects of the manures and NPK fertilizer on soil properties are shown in Table 3. Soil pH tended to increase slightly at the manure equivalent with $300 \mathrm{~kg} \mathrm{Nha}^{-1}$, then dip at the highest rate of $450 \mathrm{~kg} \mathrm{Nha}^{-1}$. This is in line with other reports by Jarvis and Robson (1983), which showed that although organic matter has a buffering effect on soil $\mathrm{pH}$ change, acidity may increase or decrease depending on other related factors such as rate of cation removal, concentration of associated anions, type of organic material and intensity of microbial decomposition. 
Organic matter (OM) levels increased greatly above pre-treatment levels, as would be expected, but interactive effects between manure type and rate indicate only PG as showing further increase in OM content at higher levels of application. The other manures and NPK $15^{3}$ all showed steady decrease in soil OM after the $150 \mathrm{~kg} \mathrm{Nha}^{-1} \mathrm{rate}_{\text {of }}$ application. Higher levels of microbial decomposition, as more energy sources become available, would seem to explain this.

Available $\mathrm{P}$ increased sharply with increase in manure addition, as would be expected (Enwezor, Udo, \& Sobulo, 1981) since organic materials are the main source of $P$ in sandy ultisols. The PM treated plots showed lowest content of $\mathrm{P}$ even though $\mathrm{P}$ content in the manure material was comparable with that of PG. This may be related to the lower test level of $\mathrm{OM}$ and $\mathrm{Ca}$ in PM. Exchangeable $\mathrm{Ca}, \mathrm{Mg}$ and $\mathrm{K}$ were not particularly affected by the manure applications due, likely, to their low contents in manures compared to bulk soil where soil minerals constitute their main source.

Effective cation exchange capacity (ECEC) increased significantly $(\mathrm{P} \leq 0.05)$ with increasing rates of manure addition. Organic matter, of course, is the major centre of ion exchange activity in a sandy soil. The ECEC values under NPK fertilizer remains same across treatment levels and confirm the high impact of OM on CEC. For similar reasons base saturation (BS) also increased with manure rates but showed no response to NPK $15^{3}$ and PW. The changes in these properties under PW treatment has shown strong similarity to observations for PM, PG and even NPK.

\subsection{Effects of Manure Types and Rates on Plant Growth}

The responses of growth parameters to manure rates are summarised in Table 4. Figures 1, 2 and 3 showed a comparative effect on plant growth among manure types and also NPK. Plant height (Figure 1), leaf surface area (LSA) (Figure 2) and fruit yield of garden eggs (Figure 3) increased sharply and by equal gradients among PM, PW and NPK at the first rate of manure application $\left(150 \mathrm{kgha}^{-1}\right)$. This compares PW favourably with PM and even NPK, while increase of height was highest at rate of $150 \mathrm{kgha}^{-1}$ for PM, PG and NPK it continues till rate of 350 $\mathrm{kgha}^{-1}$ for PW (Figure 1). The optimum rate of application should therefore generally lie at 150 or slightly above these manures and NPK $15^{3}$ on this soil type. Similarity of impact among the manures further confirms the fertilizer potentials of PW. All the yield parameters were higher for the three manures than for the NPK. A similar observation was made by Schjonning, Christensen and Carstensen (1994). Microbial activity and the presence of a wider mix of nutrients in organic materials would predict a higher response to manures than to inorganic fertilizer on acid soils under a heavy rainy weather. Soluble nutrients (which inorganic fertilizers supply in a flush) are readily leached or removed in runoff water. Manures release nutrients slowly as mineralization proceeds.

The correlation matrix given on Table 5 shows generally high positive correlations between soil available $\mathrm{P}$, the basic cations - $\mathrm{Ca}, \mathrm{Mg}$, Na and $\mathrm{K}$ - and the yield parameters (plant height, LSA and fruit yield). It is notable that pond waste water ranks virtually higher than the other manures and NPK $15^{3}$ in supporting the growth and yield of garden egg grown on this ultisol.

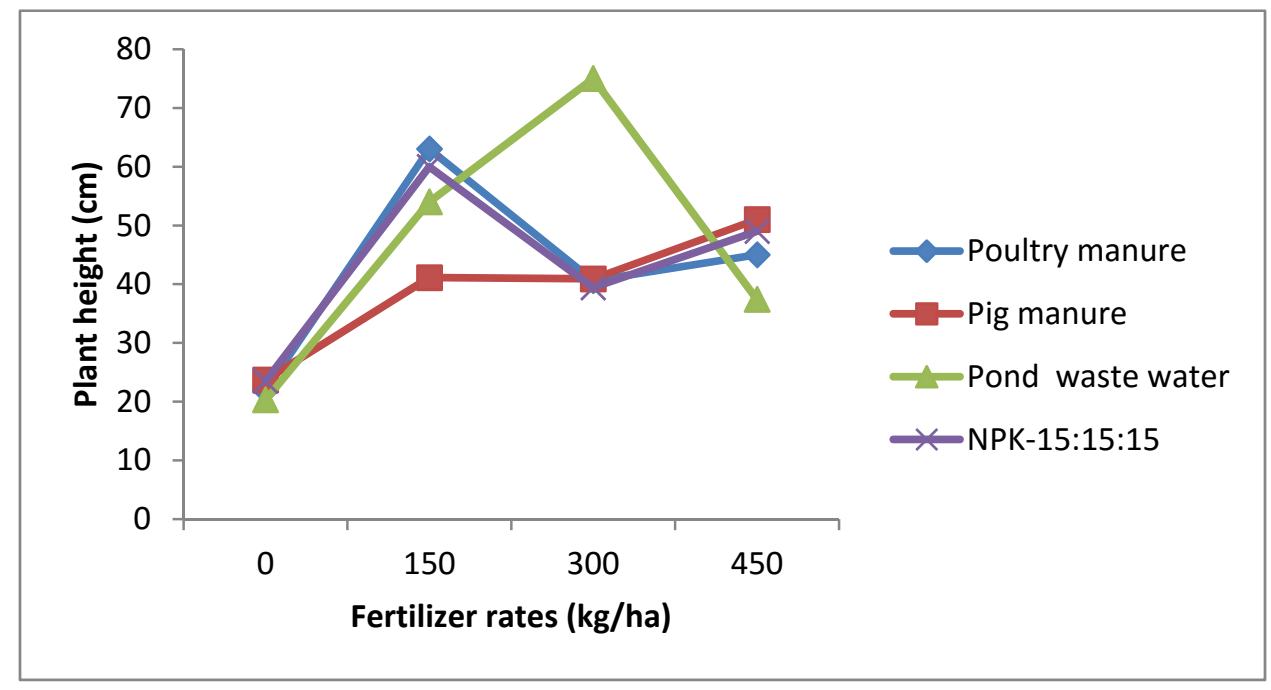

Figure 1. Effects of fertilizer rates on plant height 


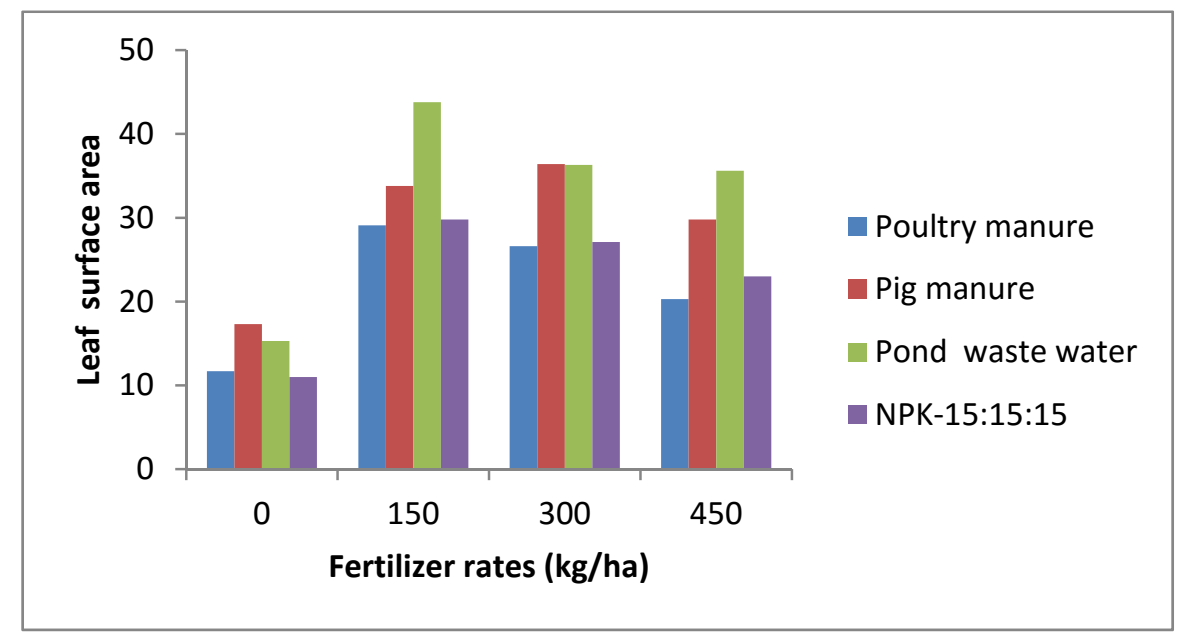

Figure 2. Effects of Manure rates on leaf surface area

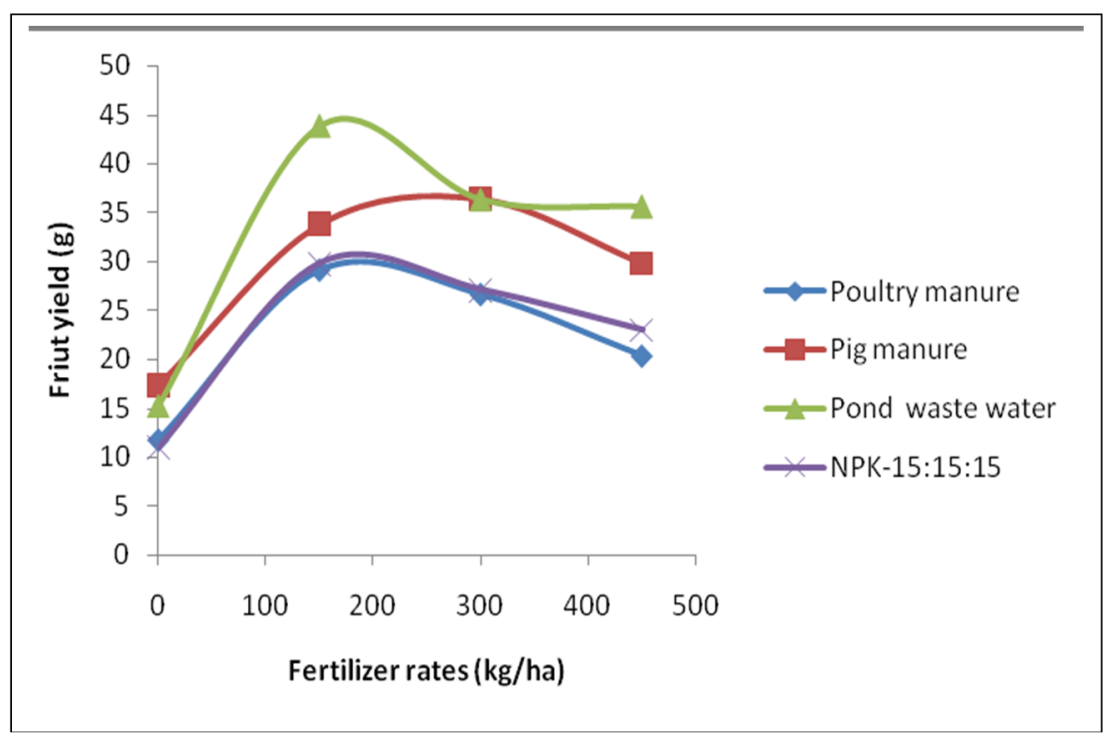

Figure 3. Effects of Manure Rate on fruit Yield of garden egg

Table 3. Effects of Manure Treatments on Soil Chemical Properties

\begin{tabular}{|c|c|c|c|c|c|c|c|c|c|c|c|c|c|c|}
\hline \multirow{4}{*}{ Soil Properties } & \multirow{4}{*}{$\begin{array}{l}\text { Control } \\
\text { Trt }\end{array}$} & \multicolumn{12}{|c|}{ Manure Types and Rates in $\mathrm{Kgha}^{-1}$} & \multirow{4}{*}{ LSD (0.05) } \\
\hline & & & $\mathbf{P M}$ & & & PG & & & PW & & & NPK & & \\
\hline & & 150 & 300 & 450 & 150 & 300 & 450 & 150 & 300 & 450 & 150 & 300 & 450 & \\
\hline & & \multicolumn{12}{|c|}{ Test Values AfterManure Application } & \\
\hline $\mathrm{pH}\left(\mathrm{H}_{2} \mathrm{O}\right)$ & 5.72 & 5.73 & 5.60 & 5.60 & 5.70 & 5.90 & 5.70 & 5.60 & 5.80 & 5.10 & 5.60 & 5.90 & 5.50 & 0.37 \\
\hline $\mathrm{EC}(\mathrm{ds} / \mathrm{m})$ & 0.39 & 0.03 & 0.04 & 0.06 & 0.05 & 0.07 & 0.08 & 0.06 & 0.06 & 0.08 & 0.08 & 0.06 & 0.07 & 0.02 \\
\hline $\mathrm{OM}(\%)$ & 2.08 & 6.25 & 5.53 & 5.91 & 5.84 & 6.46 & 7.67 & 8.23 & 5.37 & 6.21 & 8.23 & 5.37 & 6.21 & 0.39 \\
\hline TN (\%) & 0.16 & 0.16 & 0.17 & 0.19 & 0.15 & 0.18 & 0.19 & 0.17 & 0.15 & 0.16 & 0.19 & 0.16 & 0.18 & 0.04 \\
\hline Avail. P (mg/kg) & 8.88 & 17.47 & 12.14 & 12.30 & 9.09 & 26.21 & 22.70 & 22.93 & 22.23 & 22.40 & 16.97 & 29.41 & 24.56 & 3.02 \\
\hline Exch. $\mathrm{Ca}(\mathrm{cmol} / \mathrm{kg})$ & 5.20 & 3.11 & 3.68 & 3.25 & 6.55 & 6.45 & 6.05 & 4.98 & 3.25 & 4.05 & 2.85 & 2.96 & 4.85 & 0.13 \\
\hline Exch. $\mathrm{Mg}(\mathrm{cmol} / \mathrm{kg})$ & 1.45 & 1.25 & 1.30 & 1.55 & 1.73 & 2.45 & 2.05 & 1.65 & 1.50 & 1.68 & 0.97 & 0.85 & 1.65 & 0.05 \\
\hline Exch. K (cmol/kg) & 0.07 & 0.45 & 0.86 & 0.23 & 0.54 & 0.42 & 0.44 & 0.20 & 0.41 & 0.62 & 0.45 & 0.30 & 0.34 & 0.06 \\
\hline $\mathrm{ECEC}(\mathrm{mg} / \mathrm{kg})$ & 5.85 & 7.23 & 11.37 & 10.11 & 7.23 & 11.37 & 10.11 & 7.17 & 7.26 & 11.03 & 5.84 & 5.86 & 4.73 & 0.51 \\
\hline BS (\%) & 59.69 & 71.94 & 72.01 & 72.73 & 68.58 & 81.70 & 84.17 & 76.24 & 66.90 & 57.90 & 72.57 & 67.13 & 42.39 & 0.25 \\
\hline
\end{tabular}


Table 4. Effects of Manure Type and Rate on the Growth Parameters and fruit Yield of garden egg

\begin{tabular}{|c|c|c|c|c|c|c|c|c|c|c|c|c|}
\hline Fertilizer type & \multicolumn{3}{|c|}{$\overline{\mathrm{PM}}$} & \multicolumn{3}{|c|}{ PG } & \multicolumn{3}{|c|}{$\overline{\mathrm{PW}}$} & \multicolumn{3}{|c|}{ NPK: $15^{3}$} \\
\hline \multirow{2}{*}{$\begin{array}{c}\text { Rates (N-Equivalent) } \\
(\mathrm{kg} / \mathrm{ha})\end{array}$} & Plant & LSA & Fruit & Plant & LSA & Fruit & Plant & LSA & Fruit & Plant & LSA & Fruit \\
\hline & $\begin{array}{l}\mathrm{Ht} \\
(\mathrm{cm})\end{array}$ & $\left(\mathrm{cm}^{2}\right)$ & $\begin{array}{c}\text { Yield } \\
\text { (g) }\end{array}$ & $\begin{array}{l}\mathrm{Ht} \\
(\mathrm{cm})\end{array}$ & $\left(\mathrm{cm}^{2}\right)$ & $\begin{array}{l}\text { Yield } \\
\text { (g) }\end{array}$ & $\begin{array}{l}\mathrm{Ht} \\
(\mathrm{cm})\end{array}$ & $\left(\mathrm{cm}^{2}\right)$ & $\begin{array}{l}\text { Yield } \\
(\mathrm{g})\end{array}$ & $\begin{array}{l}\mathrm{Ht} \\
(\mathrm{cm})\end{array}$ & $\left(\mathrm{cm}^{2}\right)$ & $\begin{array}{l}\text { Yield } \\
(\mathrm{g})\end{array}$ \\
\hline 0 & 21.9 & 35.9 & 11.7 & 23.7 & 34.2 & $\begin{array}{ll}17.3 \\
\end{array}$ & 20.3 & 33.6 & 15.3 & 23.5 & 36.7 & 11.0 \\
\hline 150 & 63.0 & 69.2 & 29.1 & 41.1 & 66.3 & 33.8 & 54.0 & 65.7 & 43.8 & 60.0 & 64.9 & 28.8 \\
\hline 300 & 40.6 & 62.6 & 26.6 & 40.9 & 65.3 & 36.4 & 75.0 & 63.4 & 36.3 & 39.4 & 68.4 & 27.1 \\
\hline 450 & 45.0 & 41.6 & 20.3 & 51.0 & 50.2 & 29.8 & 37.4 & 59.9 & 35.6 & 49.0 & 40.6 & 23.0 \\
\hline $\operatorname{LSD}(0.05)$ & 14.6 & 14.3 & 8.3 & 5.2 & 13.5 & 7.4 & 10.3 & 13.1 & 10.6 & 13.4 & 15.1 & 7.3 \\
\hline
\end{tabular}

Note. $\mathrm{PM}=$ Poultry manure; $\mathrm{PG}=$ Pig manure; $\mathrm{PW}=$ Fish pond waste water; LSA = leaf surface area

Table 5: Relationship between Growth and yield of garden eggs and selected soil properties

\begin{tabular}{|c|c|c|c|c|c|c|c|c|c|c|c|c|c|c|c|}
\hline & $\mathrm{pH}$ & EC & $\mathrm{OM}$ & $\mathrm{TN}$ & $P$ & $\mathrm{Ca}$ & $\mathrm{Mg}$ & $\mathrm{Na}$ & $\mathrm{K}$ & EA & ECEC & BS & PLH & LSA & WF \\
\hline $\mathrm{pH}$ & 1 & & & & & & & & & & & & & & \\
\hline $\mathrm{EC}$ & -.102 & 1 & & & & & & & & & & & & & \\
\hline $\mathrm{OM}$ & .181 & .029 & 1 & & & & & & & & & & & & \\
\hline $\mathrm{TN}$ & .291 & .414 & $.607^{* *}$ & 1 & & & & & & & & & & & \\
\hline $\mathrm{P}$ & .010 & -.275 & -.001 & -.251 & 1 & & & & & & & & & & \\
\hline $\mathrm{Ca}$ & -.173 & -.292 & .148 & -.229 & .362 & 1 & & & & & & & & & \\
\hline $\mathrm{Mg}$ & -.422 & -.227 & .021 & -.356 & .356 & $.804 * *$ & 1 & & & & & & & & \\
\hline $\mathrm{Na}$ & $-.510^{*}$ & -.303 & .038 & -.115 & -.080 & .389 & .373 & 1 & & & & & & & \\
\hline $\mathrm{K}$ & -.279 & -.325 & .070 & -.284 & .089 & $.472^{*}$ & .314 & $.546^{*}$ & 1 & & & & & & \\
\hline EA & -.380 & -.037 & -.295 & -.350 & -.079 & .135 & .042 & .298 & .298 & 1 & & & & & \\
\hline ECEC & -.048 & -.130 & .038 & -.165 & $.449 *$ & $.461 *$ & .397 & .129 & .358 & .290 & 1 & & & & \\
\hline BS & .057 & -.144 & .262 & .047 & .315 & .332 & $.454^{*}$ & .164 & .206 & $-.609^{* *}$ & .348 & 1 & & & \\
\hline PLH & -.403 & -.295 & -.200 & $.551^{*}$ & .221 & .292 & .288 & $.520^{*}$ & $.702^{* *}$ & $.508^{*}$ & .224 & .080 & 1 & & \\
\hline LSA & -.254 & -.206 & -.025 & -.148 & .433 & $.465^{*}$ & $.558^{*}$ & .375 & $.475^{*}$ & .013 & .140 & .321 & $547^{*}$ & 1 & \\
\hline WF & -.345 & -.341 & .009 & -.330 & .416 & $.678^{* *}$ & $.703 * *$ & $.517^{*}$ & 420 & .377 & .425 & .308 & $.666^{* *}$ & $.662 * *$ & 1 \\
\hline
\end{tabular}

Note. * Significant at $\mathrm{P}<0.05 ; * *$ Significant at $\mathrm{P}<0.01$.

\section{Conclusion}

The results of the experiment demonstrated that fish pond waste water could be used as organic fertilizers. The results of this experiment have indicated that amounts that can supply $\mathrm{N}$ at $150-300 \mathrm{~kg} \cdot \mathrm{ha}^{-1}$ will modify soil properties positively and support high yields. Higher rates are not necessary or economical for the soil type under study. It is therefore recommended that for acid sandy ultisols regular doses of manures at rates of $150-300 \mathrm{~kg}$ $\mathrm{Nha}^{-1}$ should be applied in order to sustain fertility. Pond water effluent, wherever it is available, should be considered an important fertilizer, and it will also serve the needs of irrigation in the dry season. Large farms should as a matter of policy in their fertility management programme include aquaculture projects in order to have access to pond effluent. This study has also established that fish pond waste water ranks with poultry manure and pig manure as an organic fertilizer.

\section{References}

Ayeni, L. S., \& Adetunji, M. T. (2010). Integrated application of poultry manure and mineral fertilizer on soil chemical properties, nutrient uptake, yield and growth components of maize. Nature and science, 8(1), 60-67.

Blair, N., Faulkner, R. D., Till, A. R., \& Prince, K. E. (2003, July). The impact of plant residues with different breakdown rates on soil carbon and soil structure. In Proc. 16th ISTRO Conference (pp. 175-181).

Enwezor, W. O., Udo, E. J., \& Sobulo, R. A. (1981). Fertility status and productivity of the acid sands. Acid sands of Southeastern Nigeria. Soil Science Society of Nigeria Special Monograph, Lagos, Nigeria, 56-76.

FAO (Food and Agriculture Organization of the United Nation). (2014). The state of world fisheries and aquaculture. Opportunities and Challenges, FAO Rome, 243pp. 
Gomez, K. A., \& Gomez, A. A. (1984). Statistical procedure for agricultural research (2nd Ed.). John Wiley and Sons, New York, U. S. A., 680pp.

Hati, K. M., Swarup, A., Dwivedi, A. K., Misra, A. K., \& Bandyopadhyay, K. K. (2007). Changes in soil physical properties and organic carbon status at the topsoil horizon of a vertisol of central India after 28 years of continuous cropping, fertilization and manuring. Agriculture, ecosystems \& environment, 119(1), 127-134.

Iren, O. B., Akpan, J. F., Ediene, V. F., \& Asanga, E. E. (2015). Influence of cassava peels and poultry manure-based compost on soil properties, growth and yield of waterleaf (Talinum triangulare Jacq) in an ultisol of south-eastern Nigeria. Journal of Soil Science and Environmental Management, 6(7), 187-194.

Iren, O. B., Asawalam, D. O., Osodeke, V. E., \& John, N. M. (2011). Comparative effects of animal manures and urea fertilizer on soil properties in a rainforest ultisol. Journal of Agricultural Research and Policies, 6(2), 51-56.

Jarvis, S. C., \& Robson, A. D. (1983). The effects of nitrogen nutrition of plants on the development of acidity in Western Australian soils. I. Effects with subterranean clover grown under leaching conditions. Crop and Pasture Science, 34(4), 341-353.

John, N. M., Uwah, D. F., Iren, O. B., \& Akpan, J. F. (2013). Changes in Maize (Zea mays L.) Performance and Nutrients Content with the Application of Poultry Manure, Municipal Solid Waste and Ash Composts. Journal of Agricultural Science, 5(3), 270-277.

Kendrick, D. (2005). Muskegon County Wastewater Management System Clean and Pure Water: The Essential Ingredient. Muskegon County Department of Public Works (pp. 34-38).

Schjønning, P., Christensen, B. T., \& Carstensen, B. (1994). Physical and chemical properties of a sandy loam receiving animal manure, mineral fertilizer or no fertilizer for 90 years. European Journal of Soil Science, 45(3), 257-268.

Udo, E. J., Ibia, T. O., Ogunwale, J. A., Ano, A. O., \& Esu, I. E. (2009). Manual of soil, plant and water analysis. Sibon Book Limited, Lagos. pp, 82-92.

Yu, W., Ding, X., Xue, S., Li, S., Liao, X., \& Wang, R. (2013). Effects of organic-matter application on phosphorus adsorption of three soil parent materials. Journal of soil science and plant nutrition, 13(4), 1003-1017.

\section{Copyrights}

Copyright for this article is retained by the author(s), with first publication rights granted to the journal.

This is an open-access article distributed under the terms and conditions of the Creative Commons Attribution license (http://creativecommons.org/licenses/by/3.0/). 